\section{Göttingen physics: can an historic department be saved?}

\section{Göttingen}

Tre eminent faculty of physics at the University of Göttingen, built up in the early 1900 s through clever appointments of the Prussian ministry of culture and grants from the Rockefeller Foundation, is being threatened by outside forces. The problems, brought on in part by the critical economic situation in the Land (state) of Lower Saxony, are symptomatic of the difficulties facing many universities in northern West Germany.

Physicists at the University of Göttingen spoke last week of the danger of a Götterdämmerung _ - 'twilight of the gods' - that could drive their faculty, and perhaps the entire university, into irreversible decline.

Lower Saxony is suffering particularly from setbacks in agriculture and oil, two of its largest cconomic resources. Oil prices have dropped; and a court decision a few years ago required Lower Saxony's government to share its oil profits with the other Länder. Similar difficulties exist in neighbouring North Rhine-Westphalia (see Nature 332, 298; 1988).

Universities all over West Germany have been filled far beyond capacity since the early 1980 s and the number of students has unexpectedly continued to rise in 1988. Göttingen currently has 30,000 students, compared with 3,000 in the 1930 s.

The situation in northern Germany contrasts with that in Bavaria and BadenWürttemberg, which inherited an abundance of technology-oriented industry (such as Siemens in Munich) in the realignment of companies in West Germany after the Second World War. These southern Länder, which used to be thought of as agricultural backwaters, are now booming.

Members of the physics faculty in Göttingen say that it has not completely recovered from the effects of the Nazi era. Due to the banning of Jews from the civil service in 1933, Göttingen lost Max Born, James Franck, Richard Courant and many other theoretical physicists and mathematicians in one blow.

The current austerity measures include a cut in the number of tenured faculty and a reduction of at least 3.5 per cent in expenditures for shorter-term personnel over four years. These cuts brought students and professors onto the streets in May 1987.

In the view of Götingen physicist Klaus-Peter Lieb, Göttingen faces a critical period in the next few years. A wave of retirements will mean that the university will face tough choices in hiring replacements and paying their not insignificant equipment costs.

Lieb admitted that the university is well provided with both outside funding and the infrastructure required to do good research. But continuing budget cuts might start an irreversible slide into mediocrity. Lieb and the other physicists are clamouring for the recognition of the special status of Göttingen - Lower Saxony's oldest and largest university from the government.

The Lower Saxony Science Ministry has established a 'University Structure Commission' of experts to investigate the options for restructuring the educational system. Its report, expected by the end of the year, may encourage the government to reconsider its priorities.

Steven Dickman

\section{Sydney}

A FORMER chief justice of Australia will chair a special committee convened to investigate allegations of scientific fraud against Dr William McBride, founder and honorary director of the private research institute Foundation 41. The committee will also include two medical academics.

Foundation 41 has convened the investigation itself after several other relevant organizations declined to do so (see Nature $332,671 ; 1988)$. The research in question involves a study of hyoscine, an anticholinergic medication, and its potential for causing birth defects in rabbits. Two junior researchers who worked on the study claimed McBride adulterated the results before they were submitted to the Australian Journal of Biological Sciences.

\section{University cuts in the 1990s}

London

THE financial squeeze on British universities in the 1980 s has prompted university heads to lay down new guidelines for pricing university contracts. Under the new system, research in universities will be more expensive for companies and government departments, which hitherto have paid at rates well below market value and well below the real cost of the contracts to the universities.

A review by the Committee of ViceChancellors and Principals (CVCP) points out that, when universities are taking on more outside contracts in a bid to increase their income, undercharging means that more contracts lead to increased deficits.

Universities are advised by the University Grants Committee (UGC) to price outside contracts by calculating the direct cost and adding 40 per cent to cover overheads. But in reality, most universities charge much less than this, allowing only about 12 per cent on average for overheads according to the CVCP.

One reason that universities undercharge is their fear of losing contracts; another is that, in academic circles, charging for overheads is considered a luxury. With the total annual income from universities' contracts at between $£ 150$ and $£ 200$ million this luxury costs them around about $£ 40$ million a year.

The CVCP suggests that charging about 60 per cent of the direct cost of a contract would cover the overheads on recurrent costs, such as salaries. If universities were also to charge overheads on capital costs, such as buildings, then the total would be around 105 per cent, though these figures would vary between departments and between universities. The new system could bring universities almost $£ 200$ million more each year.

CVCP stresses that these proposals are flexible. If a university feels a contract is of long-term benefit, it should be free to charge less. And, conversely, if the university wants to make a profit, it should charge more. The point the committee emphasizes is that universities must be aware of whether or not they are subsidizing industry. The CVCP say that, at present, 95 per cent of them are doing so unawares.

The proposals follow an interim $\mathrm{CVCP}$ report, last year, to which industry generally responded favourably. But industries also said they would expect a more professional service from universities.

Later this month, this year's CVCP report will go to representatives of industry and other bodies as well as to finance officers of universities.

Christine McGourty 